\title{
Performance evaluation of entrepreneurship teachers in accounting vocational program
}

\author{
Irena Puspitaningratri *, Nur Hidayanto Pancoro Setyo Putro \\ Universitas Negeri Yogyakarta. \\ Jl. Colombo No.1, Depok, Sleman, Daerah Istimewa Yogyakarta 55281, Indonesia. \\ * Corresponding Author. Email: irenapus96@gmail.com
}

\section{ARTICLE INFO}

\section{Article History}

Received:

10 June 2020;

Revised:

11 January 2021;

Accepted:

22 January 2021;

Available online:

14 August 2021

\section{Keywords}

Creative;

Entrepreneurship

products;

Evaluation;

Teachers' performance

\begin{abstract}
This study aimed to discover the teachers' performance of the PKK Accounting Expertise Program at State SMK 1 Samigaluh based on primary duties. This study was an evaluation using the discrepancy evaluation model. The study subjects were PKK teachers of State SMK 1 Samigaluh. Information sources for the study were the headmaster, six colleagues, and 52 students. The instruments used were questionnaires, assessment sheets, and documentation sheets. The headmaster presented an excellent assessment of the PKK subject teachers of 92.81. In contrast to the headmaster, colleagues and students presented good assessments of the PKK subject teachers. According to colleagues, the PKK subject teachers' performance assessment was 86.42 , while, according to students, it was 86.67 . Based on the average performance assessment, the PKK teachers of Accounting Expertise and Institutional Financial at State SMK 1 Samigaluh were categorized as good. The headmaster presented the highest score than other assessments on all primary duties.
\end{abstract}

This is an open access article under the CC-BY-SA license.

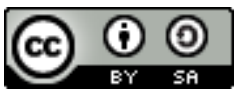

How to cite:

Puspitaningratri, I., \& Putro, N. H. P. S. (2021). Performance evaluation of entrepreneurship teachers in accounting vocational program. Jurnal Pendidikan Vokasi, 11(1), 47-58. https://doi.org/10.21831/jpv.v11i1.34933

\section{INTRODUCTION}

Vocational high school or "Sekolah Menengah Kejuruan (SMK)" is vocational education at the secondary level. SMK has a mission to generate competitive, skillful, characterized, and independent graduates. In realizing the mission, curriculum updates are necessary. Curriculum updates in SMK were periodically conducted in 2006 with the Education Unit Level Curriculum, 2013 Curriculum, and annual revision of the 2013 Curriculum. Entrepreneurship is one of the competency areas as the standard of graduate criteria or "Standar Kriteria Lulusan (SKL)" of SMK. The government carried out this action to generate SMK graduates who are skillful in becoming laborers and can also open jobs independently. Until recently, the number of unemployed from SMK is on the highest rank.

According to Badan Pusat Statistik Republik Indonesia (2019) data in February 2019, the Open Unemployment Rate (OUR) for vocational high school was $8.63 \%$, diploma was $6.89 \%$, high school was $6.78 \%$, university was $6.24 \mathrm{a} 5$, middle school was $5.04 \%$, and elementary school was $2.65 \%$. Concerning this problem, SMK's curriculum updates were carried out, including the lesson on entrepreneurship. The entrepreneurship subject in SMK changed its name from entrepreneurship or "Kewirausahaan (KWU)" in 2006 to Crafts and entrepreneurship or "Prakarya dan Kewira- 
usahaan (P-KWU)" in 2013, and the last was creative products and entrepreneurship od "Produk Kreatif dan Kewirausahaan (PKK)" in 2017.

Creative products are goods encompassing attempts to develop a goods or product to attract customers' attention. Meanwhile, the general definition of entrepreneurship education is a process that implements principles and methods leading to life skills formation on students through an integrated curriculum developed by the school. Entrepreneurship education aims to create humans as a whole, as humans with character, comprehension, and skills as entrepreneurs. Entrepreneur expertise and skills are mostly acquired from entrepreneurship education (Bahroini, 2018). Entrepreneurship is a process of creating something new (creative) and different (innovative) that provides added value. Entrepreneurship is translated verbatim as an intermediary and as an independent attitude and behavior that combines the elements of creation, sensation, challenge, hard work, and satisfaction for maximum achievement (Rusdiana, 2014).

Based on several definitions above, in short, creative products and entrepreneurship can be defined as an effort to develop a goods/product to attract customers and the ability to independently create a creative and innovative thing by combining the elements of creation, sensation, challenge, hard work, and satisfaction for maximum achievement. Sumarno and Gimin (2019) stated that PKK subject integrates fields/programs/expertise competencies in entrepreneurship, i.e., learn the enterprise from its expertise, plan the creative product, produce the product, calculate the feasibility, market the product, and arrange the enterprise finance. This subject develops entrepreneurship attitude, knowledge, skills, and practices.

The difference between the PKK subject and the previous entrepreneurship subject lies in the longer learning duration and the teacher determination. The learning duration was increased from the last 5 hours to 7 hours in the XI class and 8 hours in the XII class. The duration addition is expected to hone students' skills and grow entrepreneurial spirit in students. PKK subject is provided to all SMK expertise programs. The current PKK teacher should be a productive teacher instead of the previously adaptive teacher. It is intended so that the entrepreneurship skills obtained by students met the respective expertise program. The creative products and entrepreneurship subject in the revised 2013 curriculum put forward students' cognitive aspects, soft skills, and hard skills. It is carried out by incorporating technologies and entrepreneurship. The subject update is expected to encourage students' productivity, creativity, and innovativeness to follow the demanding, qualified young generation market.

According to Suherman (2010), entrepreneurship education consists of theories, practices, and implementation. Theories are used to direct students on entrepreneurship knowledge, which then reaches and fills students' cognitive aspects to trigger them to entrepreneurship, while practices are intended to implement the theories. This combination of theories and practices provides students with benefits of entrepreneurship education for both themselves and others. Sumarsono (2010) also stated that entrepreneurship cannot only be taught in a seminar or a book but requires an actual practice, example, and verification to shape an entrepreneurship ability. Transmission is the best way possible.

The observation results of Utami (2019) illustrated that the PKK subject is still not parallel with the objectives. In practice, teachers mostly gave theories which not compensated with practices to train students. Teachers only gave teaching materials of handouts/student working sheets and practice assignments at the end. It exposed students to little experience in creating something. Therefore, students' interest in entrepreneurship remains low. Students felt unaccompanied by the subject teachers in discovering more in-depth regarding entrepreneurship.

A study conducted by Suarya et al. (2018) obtained results of: 1.) The professionalism of the craft and entrepreneurship teachers reviewed from students' perspective was low. Competencies that met the criteria were only three out of four competencies required by Government Regulation No. 74 of 2008 (Presiden Republik Indonesia, 2008) and Regulation of the Minister of National Education of the Republic of Indonesia Number 16 of 2007 (Menteri Pendidikan Nasional Republik Indonesia, 2007a) i.e., professional, personality, and social competencies; 2.) On the pedagogic competency, teachers had not met all required criteria, i.e., the criteria of learning design and educational learning implementation, where teachers were not always be based on the lesson plans in their teachings. 
An interview with one of the PKK teachers at SMK 1 Samigaluh showed PKK teachers' problems. Teachers who teach the PKK should be productive accounting teachers caused the entrepreneurship general materials delivery was not maximum because teachers were not equipped with adequate entrepreneurship materials. The policy regarding PKK subject teachers that productive teachers should carry out causes problems at schools. For instance, a school encounters trouble in finding productive teachers to teach the subject. Another problem is the low performance of teachers. An example is creating both the short- and long-term learning plan, which causes the learning to be unprepared. Teachers also communicated the difficulty in optimizing the additional learning period of 7 hours for the XI class and 8 hours for the XII class.

The success of curriculum execution is achieved by appropriate cooperation between several parties, e.g., the school and teachers. Teachers directly communicate to students, and hence, the basic level of the curriculum execution process is when learning occurs. The learning process carried out by teachers is what is expected to deliver students to the predetermined learning objectives. Ismail (2010) explained that performance is one's overall success level in a certain period in conducting their jobs, compared to various possibilities, such as work result standards, targets, aims, or criteria previously determined and agreed upon. Husein (2017) expressed that in discovering someone's or an organization's performance, the reference is activities when they did the primary duties of their responsibilities. That is, one's performance qualification level is always associated with their routine duty.

From the various definitions, it is concluded that performance is an achievement of someone in conducting their duties or jobs in a certain period according to the predetermined standards and criteria for the job. Someone's achievement in an organization is measured using the performance assessment. Teachers' performance is teachers' behavior in executing their jobs as educators. According to Regulation of the Minister of National Education of the Republic of Indonesia Number 41 of 2007 regarding the process standard for elementary and secondary education units, it is described that teachers' performance is the teaching achievement resulted from teachers' activities in executing their primary duties and functions based on concrete realization as the logical consequence of education professional staff (Menteri Pendidikan Nasional Republik Indonesia, 2007b).

Teachers' performance encompasses all activities or behaviors of teachers to achieve results and objectives. The performance is assessed from all aspects, i.e., the viewpoints of students and teachers. Teachers' performance assessed from students' viewpoints aims to generate positive responses against students' talents and interests through learning processes. Meanwhile, from teachers' viewpoints, teachers' viewpoints aim to oblige teachers to make decisions where the learning objectives are explained clearly in behavior, which then transferred to students (Husein, 2017). Based on the explanation, it is concluded that teachers' performance is the teaching success level generated from teachers' activities in executing their primary duties and functions based on concrete realization to achieve results and objectives. Teachers' performance can be reviewed by students' and teachers' viewpoints.

The PKK learning objectives designed by the government should be delivered appropriately to students. Teachers' performance influences the achievement of the objectives of teaching the subject. Teachers should be professional in their performance to carry out the learning process according to the expectation. According to the implementation manual of teachers' performance by the Ministry of Education and Culture of the Republic of Indonesia in 2016, it is mentioned that classroom and subject teachers' performance assessment is carried out by referring to dimensions of teachers' primary duties. Dimensions of teachers' primary duties consist of planning and implementing lessons, evaluating and assessing, analyzing assessment results, and implementing follow-ups. These dimensions of primary duties are then derived into measured performance indicators in the form of teachers' works in conducting their primary duties due to teachers' competencies.

Teachers' primary duties are regulated in the Government Regulation of the Republic of Indoensia No. 74 of 2008 (Presiden Republik Indonesia, 2008) regarding teachers who stated that teachers are professional educators having primary duties to educate, teach, guide, lead, train, assess, and evaluate students' formal early childhood elementary education, and secondary education. Meanwhile, according to Presiden Republik Indonesia (2005) contained in the Government 
Regulation of the Republic of Indonesia Number 19 of 2005 Chapter VI regarding standards of educators and education personnel, it is mentioned that standards of educators include:

1.) Educators should have academic qualifications and competencies as learning agents, physically and mentally healthy; 2.) Academic qualifications referred above is a minimum education level of Bachelor or Diploma degree confirmed by certificates; and 3.) Competencies as learning agents on elementary and secondary education, and early childhood education levels encompassing: (a) pedagogic competency, (b) personality competency, (c) professional competency, and $(d)$ social competency.

Performance evaluation is an assessment process concerning performance where the results are formally documented and compared to the performance standards periodically to help the human resource management's decision-making (Wirawan, 2016). Performance evaluation is an assessment process of one's work in carrying out their jobs according to the predetermined criteria. Studies regarding teachers' performance evaluation have been conducted extensively by researchers. One example is a study by Widarsih and Faraz (2016) which measures teacher performance based on teacher competency standards, namely pedagogic, personality, social, and professional competencies. Another study regarding teacher performance evaluation was also conducted by Lalupanda et al. (2019), who used the Charlotte-Danielson evaluation method in their research. The model considers the components and elements needed in evaluating teacher performance in the teaching framework. The teaching model is then used to reference teachers, principals, or supervisors in assessing teacher performance. The framework model used as a reference is: 1.) Preparation and Planning; 2.) Class management; 3.) Learning implementation; and 4) Professional responsibility.

Although many studies were conducted regarding teachers' performance evaluation in general, limited studies were carried out to evaluate teachers' performance that particularly highlighted PKK subject teachers. Therefore, teachers' performance evaluation of the PKK subject is expected to reveal various facts related to PKK teachers' performance quality for PKK teachings' success. Even though studies themed teachers' performance evaluation was often used by researchers, performance evaluation was still necessary for practice. Teachers are central in updating and improving education quality. In other words, the essential requirement to enhance the quality of education is if educators carry out the teaching and learning process with reliable professionalism (Basri \& Akmaluddin, 2020).

In contrast with teachers' performance evaluation conducted by Widarsih and Faraz (2016) and Lalupanda et al. (2019), the evaluation method used in the present study was the discrepancy evaluation method. The evaluation was carried out by illustrating discrepancies between teachers' performance and competency criteria to be utilized. The assessment criteria of teachers' performance were based on teachers' primary duties to educate, teach, guide, lead, train, assess, and evaluate. The study objective was to discover the Teachers' Performance of Creative Products and Entrepreneurship Subjects in Accounting Expertise and Institutional Financial Competencies of SMK in Kulon Progo. The evaluation results are expected to be references and recommendations for improving teachers' performance. Therefore, the implementation of the PKK subject can be carried out following the planning.

\section{RESEARCH METHOD}

The study type used was evaluation. The evaluation study was conducted on the Teachers' Performance of Creative Products and Entrepreneurship Subject in the Accounting Expertise Program of SMK in Kulon Progo. The study design used in the evaluation was the quantitative descriptive approach. The evaluation model used was the discrepancy evaluation model. The gap evaluation model or discrepancy model emphasizes the view of gaps in program implementation. This evaluation model compares the actual performance achieved with the performance expected by the standard. The gap evaluation model or discrepancy model emphasizes the view of gaps in program implementation. This evaluation model compares the actual performance achieved with the performance expected by the standard. This evaluation model was chosen because it was to identify whether there was a gap between the actual PKK teacher performance in Kulon Progo and the PKK 
teacher performance criteria in accordance with the teacher's assignment standard (Presiden Republik Indonesia, 2003). The evaluation results were used to create a policy regarding existing programs to be improved, continued, or terminated (Kaufman, 1980).

The study was carried out in October-November 2019 in State SMK 1 Samigaluh. The study subjects were PKK subject teachers of PKK expertise competencies in State SMK 1 Samigaluh. The instruments used were questionnaires, self-assessment sheets, and documentation sheets. This study used questionnaires to obtain teachers' performance data from the headmaster, six colleagues, and 52 students from two classes. The colleague selection was based on the headmaster's recommendation, i.e., teachers who understood how PKK teachers performed their duties. Colleagues selected as respondents were teachers of the accounting expertise program for six people. Documentation sheets were used to physically prove the presence and meaningfulness of teachers' performance following teachers' statements.

The instrument validation was conducted using Pearson's Product Moment Correlation. The decision-making criteria to determine whether the research instrument is valid is if $r_{\text {count }}$ is greater than $\mathrm{r}_{\text {table }}$ at a significant level of $5 \%$, then the statement item is valid, and if $r_{\text {count }}$ is obtained less than $r_{\text {table }}$ then the instrument item in question is said to be invalid. Invalid instrument items not used in further research are considered invalid. All items in the PKK teacher performance appraisal instrument are declared valid.

The reliability test of the PKK teacher performance assessment questionnaire instrument used the reliability test with the Alpha formula using the SPSS application. This reliability test is used to determine to what extent the results of the measurement process can be trusted. Furthermore, the instrument reliability index is calculated using the Cronbach Alpha formula. If the magnitude is equal to or more than 0.7, then the instrument is classified as good. Based on the reliability test results, the questionnaire reliability coefficient was 0.950 , which means that the questionnaire reliability of students' perceptions about the performance of PKK teachers was good. The data analysis in the study was quantitative descriptive. The quantitative data analysis was carried out using a descriptive technique to describe and interpret each evaluation aspect compared with the predetermined criteria.

\section{RESULT AND DISCUSSION}

\section{Result}

According to the headmaster, colleagues, and students, the study result discussion reviews teachers' performance assessment of creative products and entrepreneurship subject teachers of the Accounting Expertise Program at State SMK 1 Samigaluh. The study was based on teachers' duties of educating, teaching, guiding, leading, training, assessing, and evaluating. The headmaster presented an excellent assessment of PKK subject teachers of 92.81. In contrast with the headmaster, colleagues and students presented good assessments to PKK subject teachers. According to colleagues, PKK subject teachers' performance assessment was 86.42, while, according to students, it was 86.67. Here is the description of the performance assessment of PKK subject teachers according to the headmaster, colleagues, and students:

Educate (mendidik) comes from the word "didik", in the Indonesian Dictionary educate is maintain and provide exercises (teachings, guidance, leadership) regarding morals and mind intelligence (Badan Pusat Pengembangan dan Pembinaan Bahasa, n.d.-b). Teachers are educators who become role models and identification to students and their environment. Therefore, teachers should possess particular personal quality standards encompassing responsibilities, authority, and independence (Uno \& Lamatenggo, 2016). The educating duty obtained an excellent score from the headmaster of 93.75. Colleagues presented a good assessment of 90.8, while students presented a score of 87.6, categorized as good.

The educating duty had four indicators. The first one was teachers' performances in educating were mature-behaved and could be exemplaries. According to the headmaster, the result shows that teachers had been mature-behaved and expressed exemplary values excellently to students. Teachers could be graceful and mature-behaved in getting critics and suggestions and 
demonstrating examples to students on time. According to colleagues, PKK subject teachers' performance was 93.75 , or in the good category. Meanwhile, according to students, teachers' performance was 88.2 or in the good category.

The second indicator was teachers' performance demonstrated with work ethics and responsibilities as teachers. The headmaster presented a perfect score of 100 or in the excellent category. An ideal score translated that teachers had high work ethics and responsibilities while working. According to colleagues, PKK teachers obtained a score of 90.28, or in the good category, while, according to students, it was 82.69 or in the good category. The additional blatant meeting hours of the PKK subject did not discourage teachers from teaching and had to be improved to be maximized.

The third indicator was displaying self as a dignified and independent person. Teachers should be mature in attitude and behavior and finished their jobs without asking others to help. This indicator was given a score of 87.5 from the headmaster or in the good category. According to colleagues, PKK subject teachers obtained a score of 87.5 or in the good category. Furthermore, students presented a good assessment in the category of 82.45.

The fourth indicator was being discriminatory. The headmaster presented a perfect score of 100 to PKK subject teachers. The headmaster assessed that PKK subject teachers managed to provide the same chance to their students to ask and express opinions. According to colleagues, PKK subject teachers' performance for not being discriminatory obtained an excellent score of 91.67. Meanwhile, according to students, PKK subject teachers obtained an excellent score of 95.66. Based on the three assessments, it is concluded that PKK subject teachers had been excellently providing the same chance to their students to actively participate in the learning process by asking or expressing their opinions.

The second duty of teachers is teaching. Teaching (mengajar) comes from the word "ajar", in the Indonesia Dictionary that means leads presented to others to be known (followed) (Badan Pusat Pengembangan dan Pembinaan Bahasa, n.d.-a). Teachers are obliged to help developing students learn unknown things, shape competencies, and understand the learning standards (Uno \& Lamatenggo, 2016). Teachers as educators are asked to keep up with technological advances so that the materials delivered to students are updated. The teaching duty obtained a score of 100 from the headmaster. It shows that the headmaster assessed teachers' performance in planning their learning activities to implement them. Colleagues also presented an excellent score to PKK teachers of 91.67. On the contrary, with the headmaster and colleagues, students presented a good assessment to PKK teachers with 89.72 .

The teaching duty had two indicators, i.e., planning learning activities and implementing learning activities in classes. The first indicator included syllabus formulation and lesson plans. In contrast, the second indicator included learning activity implementation by emphasizing approaches, strategies, learning sources, and media appropriate to the subject during the learning process. The headmaster presented a perfect score for both indicators. Meanwhile, colleagues presented scores of 93.75 for the first indicator and 89.58 for the second indicator. Students presented good assessments to both indicators, with 90.87 for the first and 88.58 for the second.

The third duty of teachers was guiding. Guiding (membimbing) in the Indonesia Dictionary means providing leads (lessons and such, nurturing, initial explanation) of things to be discussed and such (Badan Pusat Pengembangan dan Pembinaan Bahasa, n.d.-d). Mulyasa (2018) suggested that teachers require high competencies to execute four things as guidance. These four things are: a.) Teachers should plan the objectives and identify competencies to be achieved; b.) Teachers should discover students' engagement in learning, and the most important is that students follow the learning process both physically and psychologically; c.) Teachers should interpret learning activities; and d.) Teachers should conduct assessments.

The guiding duty obtained a score of 95 from the headmaster or in the excellent category. According to colleagues, PKK teachers' performance based on the guiding duty obtained a score of 83.33 or in the good category. Following the colleagues' assessment, students also presented a good score of 87.21. The guiding duty of teachers included five indicators. The indicator of teachers' performance in formulating learning objectives by formulating lesson plans according to the syllabus, the indicator of engaging students in the learning process, the indicator of providing help to students 
struggling to learn, and the indicator of conducting assessments to students' assignments obtained a perfect score from the headmaster. However, an indicator that obtained a relatively low score from the headmaster was teachers' performance in providing assignments that triggered students' curiosity. According to the headmaster, PKK teachers' assessment was still included in the sufficient category to provide assignments that triggered students' creativity and thought power. Also in the sufficient category was how teachers engaged students to overcome problems provided by teachers.

According to colleagues, the indicator of formulating learning objectives, providing assignments that triggered students' curiosity, and engaging students in learning obtained the same score of 83.33 or included in the good category. Meanwhile, the indicator of providing help to students struggling to learn obtained a score of 87.5, and the indicator of conducting assessments to students' assignments obtained a score of 79.17. Both were included in the good category. Students presented a similar assessment with colleagues. All guiding indicators were included in the good category, i.e., 88.46 for the first indicator, 85.82 for the second category, 88.22 for the third category, 86.54 for the fourth category, and 87.02 for the third the fifth category.

The fourth teachers' duty was leading. Leading (mengarahkan) in the Indonesia Dictionary means showing, guiding (providing leads), facing, intending (Badan Pusat Pengembangan dan Pembinaan Bahasa, n.d.-e). Teachers are leaders for students and their parents. Teachers should lead students to tackle various problems, make decisions, and find their identities. Teachers as leaders are also obliged to lead students in developing their potentials to develop good characters in overcoming real problems in society (Uno \& Lamatenggo, 2016). The leading duty obtained a score of 84.38 by the headmaster or in the good category. Colleagues presented a score of 81.77 or in the good category. Students also presented a good assessment to PKK subject teachers with a score of 85.16. The leading duty included four indicators. The four indicators of leading duty according to the headmaster, colleagues, and students are: 1.) Underlying teachers' duty of leading is leadership; 2.) Teachers' performance in providing various learning activities to lead students to acquire achievements optimally; 3.) Teachers' ability to provide leads to students regarding the activity conducted; 4.) Engaging students to participate in educating activities; and 5.) Training.

The first indicator underlying teachers' duty of leading is leadership. PKK subject teachers obtained a score of 75 or in the sufficient category from the headmaster. The headmaster assessed that teachers were adequate to invite and drive students to achieve learning objectives. Colleagues presented a good assessment to PKK subject teachers with a score of 79.17. Students also presented a good score of 84.62 to PKK subject teachers.

The second indicator is teachers' performance in providing various learning activities to lead students to acquire achievements optimally. The headmaster presented a score of 87.5 or in the good category. Colleagues also presented a good assessment to PKK teachers with a score of 85.42. Following scores from the headmaster and colleagues, students also presented a good assessment with a score of 87.74. These assessments were based on PKK teachers' activities in creating creative products such as batik, salted egg, and tempe, which are directly practiced in the production and marketing activities to lead students to product creation and entrepreneurship skills.

The third indicator was teachers' ability to provide leads to students regarding the activity conducted. The headmaster presented a perfect score of 100 to this indicator. Meanwhile, according to colleagues and students, this indicator was included in the good category with scores of 87.5 and 84.62 , respectively. The fourth indicator was engaging students to participate in educating activities. The headmaster and colleagues presented sufficient assessments of this indicator with a score of 75 . Meanwhile, according to students, it was included in the good category with a score of 83.65.

The fifth duty of teachers was training. Training (melatih) in the Indonesia Dictionary means teaching someone and such to be used (able to) conduct something, familiarize self (learning) (Badan Pusat Pengembangan dan Pembinaan Bahasa, n.d.-c). Teachers are obliged to train students in formulating basic competencies according to each student's potentials. Teachers should understand the differences between each student and the environment (Uno \& Lamatenggo, 2016). Teachers' duty of training obtained an excellent assessment from the headmaster with a score of 93.8. According to colleagues and students, teachers' duty of training was included in the good category with 83.85 and 84.86 , respectively. Teachers' duty of training was based on four indicators, which are: 1.) Mastering the scientific mindset concept that encourages the subject; 2.) Utilizing of 
Information Communication and Technology (ICT) to develop teaching materials mastery; 3.) Providing exercises according to materials and competencies to be achieved; and 4.) Providing chances to students to conduct problem-solving independently

The first indicator was mastering the scientific mindset concept that encourages the subject. This indicator encompassed two things, i.e., delivering actual information related to the subject and arranging materials consisting of appropriate information supporting students' learning process. According to the headmaster, this indicator was included in the sufficient category with a score of 75. PKK teachers of the Accounting Expertise Program were productive teachers instead of teachers with entrepreneurship specialties. Therefore, their scientific mindset concept was categorized in the sufficient category. Meanwhile, according to colleagues and students, PKK subject teachers obtained good assessments with 81.25 and 84.62 , respectively.

The second indicator was the utilization of Information Communication and Technology (ICT) to develop teaching materials mastery. According to the headmaster, this indicator was included in the excellent category with a score of 100. The headmaster assessed that the PKK teachers had utilized ICT well because they used laptops and the Internet to optimize their learning processes. Meanwhile, according to colleagues and students, this indicator was included in the good category with scores of 83.33 and 83.65 , respectively.

The third indicator was providing exercises according to materials and competencies to be achieved. This indicator obtained a perfect score of 100 from the headmaster. The headmaster perceived teachers had provided exercises and assignments according to the syllabus. Colleagues presented a good assessment of this indicator with a score of 85.42. Following the colleagues' assessment, students also presented a score of 86.65 or were included in the good category.

The fourth indicator was providing chances to students to conduct problem-solving independently. This indicator obtained an excellent assessment from the headmaster with a score of 100. Teachers had created assignments or exercises to be carried out independently by students, which were then discussed in class. Meanwhile, colleagues and students presented good assessments of this indicator. Colleagues presented a score of 85.43, while students' score was 84.62.

The sixth teachers' duty was assessing and evaluating. Assessing (menilai) in the Indonesia Dictionary means estimating or determining the score, giving scores, giving numbers (Badan Pusat Pengembangan dan Pembinaan Bahasa, n.d.-g). Meanwhile, evaluating (mengevaluasi) in the Indonesia Dictionary means giving assessment, assessing (Badan Pusat Pengembangan dan Pembinaan Bahasa, n.d.-f). Assessment or evaluation is the most complex learning aspect because it involves various backgrounds and relationships and other variables inseparable from the assessment. Learning cannot be separated from the assessment because assessment is the process of determining learning outcome quality or determining the learning objective achievement level of students (Uno \& Lamatenggo, 2016). According to the headmaster, colleagues, and students, this indicator obtained good assessments with scores of 90, 87.08, and 85.82, respectively. Teachers' duties of assessing and evaluating included four indicators, which are: 1.) Creating an authentic learning grid; 2.) Developing assessment instruments and evaluating learning processes and outcomes; 3 .) Conducting assessment and evaluation of learning processes and outcomes; and 4.) Use the information on assessment and evaluation results for various purposes.

The first indicator underlying teachers' assessment in assessing and evaluating is creating authentic learning grids. This indicator obtained a perfect score from the headmaster because PKK teachers conducted authentic assessments encompassing performance, project, portfolio, and written assessments. Colleagues and students presented good assessments in this indicator. It shows from colleagues' score of 89.58 and students' score of 83.65.

The second indicator was developing assessment instruments and evaluating learning processes and outcomes. This indicator obtained a score of 75 from the headmaster or in the sufficient category. According to colleagues, this indicator obtained an excellent assessment of 91.67. Meanwhile, according to students, this indicator obtained a good assessment of 87.02. The third indicator was conducting assessment and evaluation of learning processes and outcomes. The headmaster presented a perfect score for this indicator.

The fourth indicator is teachers' performance assessment using the information of assessment and evaluation results for various purposes. This indicator obtained a sufficient 
assessment from the headmaster with a score of 75 . Colleagues presented a good assessment with a score of 87.5. Meanwhile, students presented a score of 87.26 or in the good category. Teachers usually used students' assessments and evaluations to consider the future steps in learning processes. Learning improvements were carried out using remedial programs for students who did not achieve the Minimum Completeness Criteria or "Kriteria Ketuntasan Minimal (KKM)" and enrichment for students who completed the KKM. KKM is the target of the education unit in achieving the competence of each subject. Students who score above the KKM will be said to be competent students, while those whose scores are not above the KKM are said to be not qualified. The results can later be used as part of a component in evaluating learning programs implemented in schools.

The fifth indicator was communicating the results of assessment and evaluation to stakeholders. This indicator obtained a perfect score of 100 from the headmaster. Meanwhile, colleagues and students presented good assessments for this indicator with scores of 79.17 and 86.06, respectively. Teachers communicated the results of assessment and evaluation to students and student's parents. The information provision of assessment and evaluation results was intended to trigger improvement from teachers and students and was supported by parents. Parents were expected to offer support to their children to improve their learning continuously. Students were also expected to be encouraged to study and improve their achievements deliberately.

\section{Discussion}

The teachers' performance evaluation results of PKK subject in accounting expertise program and institutional finance were included in the good category. It shows that teachers had realized their primary duties as teachers, i.e., educate, teach, guide, lead, train, assess, and evaluate. The explanation of each teachers' duty is: 1.) The educating duty obtained a score of 90.60 and was included in the good category; 2.) The teaching duty obtained a score of 93.80 and was included in the excellent category; 3 .) The guiding duty obtained a score of 88.51 and included in the good category; 4.) The leading duty obtained a score of 83.77 and included in the good category; 5 .) The training duty obtained a score of 87.49 and included in the good category; and 6.) The assessing and evaluating duties obtained a score of 87.63 and included in the good category.

These results contrast the study results of Suarya et al. (2018) that used the formativesummative evaluation model. The study results showed that the professionalism of the craft and entrepreneurship teachers reviewed from students' perspectives was low. Competencies that met the criteria were only three out of four competencies required by Government Regulations of the Republic of Indonesia No.74 of 2008 (Presiden Republik Indonesia, 2008) and Regulation of the Minister of National Education of the Republic of Indonesia No. 16 of 2007, i.e., professional, personality, and social competencies (Menteri Pendidikan Nasional Republik Indonesia, 2007a).

This study differs from the previous three studies due to informant differences. The previous studies only used students as informants, while this study used the headmaster, colleagues, and students. Data collection from three different informants aimed to reduce biases and disadvantages from single data utilization. The triangulation theory supported the informant choice from different informant groups. Triangulation is a data validity checking technique utilizing something outside of the data to check or compare the data. The triangulation used in the present study was data triangulation. Data triangulation means using various data sources, e.g., data sourced from multiple informants or respondents (Bachri, 2010). Different informant collection was carried out to obtain data from different sides. The headmaster and colleagues had access to assess PKK subject teachers outside of classes, while students evaluated teachers' performance in classes.

According to Sukanti (2010), if the evaluation aimed to improve teachers' performance, it is best to involve many parties as evaluators, e.g., students, colleagues, administrative staff, and selfevaluation. Self-evaluation will provide perspectives regarding the performance. Performance assessments by the headmaster and supervisors were carried out to discover teachers' competencies. It is because the headmasters played a role as an evaluator and decision-maker that is related to teachers' performance. Performance assessment from colleagues was considered stable in a certain period and often had a higher predictive validity than assessments from the headmaster and supervisors. Performance assessment from colleagues was more focused on achievements and 
outcomes. Teachers' performance assessment using the self-evaluation eased teachers' improvement because teachers focused on their behaviors and attitudes and identified their strengths and weaknesses. Therefore, teachers would tend to accept their self-assessments and be proactive in building their strengths and reduce weaknesses. Performance assessment from students aimed to assess the performances in managing classes. Students were the ones contacting teachers the most, and hence, they were able to observe performance related to behaviors that might be unobserved by the headmaster.

Entrepreneurship education in SMK/MAK is carried out from the subject and applied from practices based on production and subject supporting businesses, e.g., teaching factory, techno park, business center, and student cooperative (Sumarno \& Gimin, 2019). Teaching factory learning is a learning concept in SMK based on production or service, referring to standards and procedures applied in industries and implemented in a situation that resembles industries. The teaching factory process can implement entrepreneurship to students because it integrates learning processes to create feasible products or services to add value for schools (Manalu et al., 2017). Technopark is a place or infrastructure to accommodate the production results of teaching factory to be marketed to customers or industries in need. Technopark enables efficient and fast information and technology streams between the industry and education sector and encourages potential local improvement by accelerating entrepreneurship programs in SMK (Khurniawan, 2016).

Business Center is an economic activity held by the school for the public (Sumarno \& Gimin, 2019). Hadam (in Sumarno \& Gimin, 2019) suggested that business center is controlled based on students' expertises called business center technopreneurship, such as in automotive that opens a bike workshop, in multimedia and broadcasting that opens a photo and shooting video, in audiovideo with an audio-video workshop, machinery with a welding and lathe workshop, and other business fields such as mini banks, pharmacies, health clinics, etc. Meanwhile, student cooperative is the place to implement teaching factory, technopark, and business center.

\section{CONCLUSION}

Based on the problems, objectives, analysis results, and discussion explained, the conclusions are as follow: 1.) The performance of PKK subject teachers of Accounting Expertise Program in State SMK 1 Samigaluh based on primary duties of educating, teaching, guiding, leading, training, assessing, and evaluating according to the headmaster was in the excellent category; 2.) According to colleagues, the performance of PKK subject teachers of Accounting Expertise Program in State SMK 1 Samigaluh based on primary duties of educating, teaching, guiding, leading, training, assessing, and evaluating was in a good category; 3.) The performance of PKK subject teachers of Accounting Expertise Program in State SMK 1 Samigaluh based on primary duties of educating, teaching, guiding, leading, training, assessing, and evaluating according to students was in a good category; 4.) In general, the performance of PKK subject teachers of the Accounting Expertise Program was in a good category. The headmaster assessment obtained an excellent result. However, assessments from colleagues and students were in a good category. These results can be used as a reference to improve the performance from good to excellent; and 5.) Teachers' performance improvement in mastering scientific mindset concept that encourages the PKK subject has to be developed. It can be carried out by utilizing information, communication, and technology (ICT) as reinforcement learning source. ICT mastery might help teachers prove knowledge concept mastery, search learning sources, and search broader, more relevant, and actual teaching materials.

\section{REFERENCES}

Bachri, B. S. (2010). Meyakinkan validitas data melalui triangulasi pada penelitian kualitatif. Jurnal Teknologi Pendidikan, 10(1), 46-62. http://yusuf.staff.ub.ac.id/files/2012/11/meyakinkanvaliditas-data-melalui-triangulasi-pada-penelitian-kualitatif.pdf

Badan Pusat Pengembangan dan Pembinaan Bahasa. (n.d.-a). Ajar. In Kamus Besar Bahasa Indonesia (KBBI) Online Dictionary. https://kbbi.web.id/ajar 
Badan Pusat Pengembangan dan Pembinaan Bahasa. (n.d.-b). Didik. In Kamus Besar Bahasa Indonesia (KBBI) Online Dictionary. https://kbbi.web.id/didik

Badan Pusat Pengembangan dan Pembinaan Bahasa. (n.d.-c). Melatih. In Kamus Besar Bahasa Indonesia (KBBI) Online Dictionary. https://kbbi.web.id/latih

Badan Pusat Pengembangan dan Pembinaan Bahasa. (n.d.-d). Membimbing. In Kamus Besar Bahasa Indonesia (KBBI) Online Dictionary. https://kbbi.web.id/bimbing

Badan Pusat Pengembangan dan Pembinaan Bahasa. (n.d.-e). Mengarahkan. In https://kbbi.web.id/arah. https://kbbi.web.id/arah

Badan Pusat Pengembangan dan Pembinaan Bahasa. (n.d.-f). Mengevaluasi. In Kamus Besar Bahasa Indonesia (KBBI) Online Dictionary. https://kbbi.web.id/evaluasi

Badan Pusat Pengembangan dan Pembinaan Bahasa. (n.d.-g). Menilai. In Kamus Besar Bahasa Indonesia (KBBI) Online Dictionary. https://kbbi.web.id/nilai

Badan Pusat Statistik Republik Indonesia. (2019). Keadaan angkatan kerja di Indonesia Februari 2019 (Subdirektorat Statistik Ketenagakerjaan Republik Indonesia (ed.)). BPS RI. https://www.bps.go.id/publication/2019/05/31/a96ce41f72e59d5dfb1cad9f/keadaanangkatan-kerja-di-indonesia-februari-2019.html

Bahroini, N. F. (2018). Implementasi pendidikan karakter pada mata pelajaran produk kreatif dan kewirausahaan di kelas XI Jasa Boga SMK Negeri 7 Malang [Universitas Muhammadiyah Malang]. http://eprints.umm.ac.id/43716/1/NASKAH.pdf

Basri, B., \& Akmaluddin, A. (2020). Evaluasi profesionalisme guru. JOURNAL OF EDUCATION SCIENCE, 6(1), 75-85. https://doi.org/10.3314/jes.v6i1.801

Husein, L. (2017). Profesi keguruan: menjadi guru profesional. Pustaka Baru Press.

Ismail, M. I. (2010). Kinerja dan kompetensi guru dalam pembelajaran. Lentera Pendidikan : Jurnal Ilmu Tarbiyah Dan Keguruan, 13(1), 44-63. https://doi.org/10.24252/lp.2010v13n1a4

Kaufman, R. A. (1980). Evaluation without fear. New Viewpoints.

Khurniawan, A. W. (2016). Grand design pengembangan teaching factory dan technopark di SMK. Direktorat Jendral Pendidikan Dasar dan Menengah, Kementerian Pendidikan dan Kebudayaan Republik Indonesia.

Lalupanda, E. M., Sulasmono, B. S., \& Iriani, A. (2019). Evaluasi kinerja guru SMA bersertifikasi dengan model Charlotte Danielson di SMA Negeri. Kelola: Jurnal Manajemen Pendidikan, 6(1), 11-24. https://doi.org/10.24246/j.jk.2019.v6.i1.p11-24

Manalu, S. R. I., Hermanto, S., Duling, J. R., Siswandi, G., Supriyadi, S., \& Siahaan, A. P. (2017). Tata kelola pelaksanaan: Teaching factory. Direktorat Pembinaan Sekolah Menengah Kejuruan, Kementerian Pendidikan dan Kebudayaan Republik Indonesia. http://smk.kemdikbud.go.id/uploads/filestorage/12T6YhfmJdfx9omMxkIznZN0wUhQ3gI7 hcfayTlE.pdf

Menteri Pendidikan Nasional Republik Indonesia. (2007a). Peraturan Menteri Pendidikan Nasional Republik Indonesia Nomor 16 Tahun 2007 tentang Standar Kualifikasi Akademik dan Kompetensi Guru.

Menteri Pendidikan Nasional Republik Indonesia. (2007b). Peraturan Menteri Pendidikan Nasional Republik Indonesia Nomor 41 Tahun 2007 tentang Standar Proses untuk Satuan Pendidikan Dasar dan Menengah.

Mulyasa, E. (2018). Menjadi guru profesional: Menciptakan pembelajaran kreatif dan menyenangkan (M. Mukhlis (ed.)). Rosda. 
Presiden Republik Indonesia. (2003). Undang-Undang Republik Indonesia Nomor 20 Tahun 2003 tentang Sistem Pendidikan Nasional.

Presiden Republik Indonesia. (2005). Peraturan Pemerintah Republik Indonesia Nomor 19 Tahun 2005 tentang Standar Nasional Pendidikan.

Presiden Republik Indonesia. (2008). Peraturan Pemerintah Republik Indonesia Nomor 74 Tahun 2008 tentang Guru.

Rusdiana, R. (2014). Kewirausahaan: Teori dan praktik. Pustaka Setia.

Suarya, D., Santiyadnya, N., \& Arsa, P. S. (2018). Studi evaluasi profesionalisme guru prakarya dan kewirausahaan ditinjau persepsi siwa XI MIA SMAN 4 Singaraja. Jurnal Pendidikan Teknik Elektro Undiksha, 7(1), 20-30. https://doi.org/10.23887/jjpte.v7i1.20217

Suherman, E. (2010). Desain pembelajaran kewirausahaan. Alfabeta.

Sukanti, S. (2010). Peran penilaian kinerja guru dalam pengembangan profesi pendidik. http://staffnew.uny.ac.id/upload/130799880/penelitian/PERAN+PENILAIAN+KINERJA+ GURU++DALAM+PENGEMBANGAN+PROFESI+PENDIDIK.pdf

Sumarno, S., \& Gimin, G. (2019). Analisis konseptual teoretik pendidikan kewirausahaan sebagai solusi dampak era industri 4.0 di Indonesia. JURNAL PENDIDIKAN EKONOMI: Jurnal Ilmiah Ilmu Pendidikan, Ilmu Ekonomi Dan Ilmu Sosial, 13(2), 1-14. https://doi.org/10.19184/jpe.v13i2.12557

Sumarsono, S. (2010). Kewirausahaan. Graha Ilmu.

Uno, H. B., \& Lamatenggo, N. (2016). Tugas guru dalam pembelajaran. Bumi Aksara.

Utami, A. A. N. (2019). Pengaruh pembelajaran produk kreatif dan kewirausahaan terhadap minat berwirausaha siswa di SMK Pasundan 2 Bandung (Studi kasus pada kelas XI Program Keahlian Teknik Permesianan Tahun Ajaran 2018/2019) [Universitas Pasundan]. http://repository.unpas.ac.id/43291/

Widarsih, R., \& Faraz, N. J. (2016). Evaluasi kinerja guru IPS SMP berdasarkan standar kompetensi guru di Kabupaten Kebumen. Harmoni Sosial: Jurnal Pendidikan IPS, 3(2), 177-187. https://doi.org/10.21831/hsjpi.v3i2.7646

Wirawan, W. (2016). Evaluasi teori, model, standar, aplikasi dan profesi. Rajawali Pers. 